Ethiopian Journal of Environmental Studies \& Management 8(1): 28 - 38, 2015.

ISSN:1998-0507

Submitted: August 18, 2014

doi: http://dx.doi.org/10.4314/ejesm.v8i1.3

Accepted: January 12, 2015

\title{
EFFECT OF VACANCY ON SHOPPING CENTRES' INVESTMENT RETURNS IN AKURE, NIGERIA
}

*BELLO, V.A. AND EZEOKOLI, N.B.

Department of Estate Management, Federal University of Technology, Akure, Nigeria

\begin{abstract}
The paper examined the effect of vacancy rate on the rental returns of shopping centres in six major retail areas in Akure. Data on rental values and vacancy rates in 35 shopping centres were collected from 17 estate surveying firms in Akure. The shopping centres had a total number of 1,352 rentable spaces with 1,183 occupied. The data was analysed using Descriptive statistics such as frequency distribution tables and graph, one sample $t$ - statistics and Simple Linear Regression Analysis. The result showed that vacancy in shopping centres are on the increase especially in Oke ijebu axis of Akure thereby causing a decline in the expected returns from the centres. The result further showed that as vacancy rate in shopping centres increases the rent per meter square reduces as owners tends to reduce rent to retain tenants. There is need for shopping centre developers to employ the services of the Estate Surveyors and Valuers to carry out feasibility and viability appraisal of their projects before embarking on them. This gesture will check over supply of centres.
\end{abstract}

Keywords: Investment, Rental Returns, Shopping centre, Vacancy Rate

\section{Introduction}

Shopping centres are retail properties with special qualities compared to other property investments (Gerbich, 1998). However, it appears the forces driving retail expansion all over the world have deviated from actual consumer demand. Benjamin et al. (1995) reported that the pace of shopping centre development in the United States gave an indication of this assertion. Therefore, Benjamin et al. (1998) noted that shopping centre developers who respond to a positive demand shift by building new shopping space could stand the risk of rents not increasing appreciably after the demand shift. Rather, the demand shift may induce a substantial increase in quantity supplied, and any subsequent fall in demand may significantly increase vacant space. With low demand for space in a property and vacancy rates rising through new construction, out - migration, decline in customers patronage or other means, landlords have had to offer reduced rents and significantly increased incentives in order to attract or retain tenants (Belsky and Goodman, 1996; Frank, 2010). This step at reducing the risk of vacancy through reduced rents by the landlords has also led to reduction in the expected return and hence, the investment performance of shopping centres especially in the developed nations. With vacancy on the increase and tenants having much space rental options, the negotiating power for shop spaces switches to the tenant until

*Corresponding Author: Bello, V.A.

Email: vicbellofuta@yahoo.com 
vacancies and rent come back into equilibrium (Hartzell and Webb, 1993; Belsky and Goodman, 1996).

Belsky and Goodman (1996) opined that changes in the rents depend on the deviation of the rental vacancy rate from its natural level. In other words, the natural rental vacancy rate is that rate at which there is no upward or downward pressure on rents. The natural vacancy rate varies across time, space and structural type. The natural rate depends upon factors that affect the rate at which vacant units come on the market and the average duration of vacancies. In addition, the level of the natural vacancy rate has direct implications for the return on property investment. In the long-run equilibrium, the lower the natural vacancy rate, the greater the amount of rent generated by a given rental property, everything else held constant (Hagen and Hasen, 2010). If the natural vacancy rate declines over time, the return on rental property investment will rise ceteris paribus. The higher the rate at which tenants take up leases in a shopping centre (demand), the lesser the void/vacancy in such a centre and vice versa (Rosen and Smith, 1983). This low vacancy therefore, guarantees the rental return from such shopping centre.

However, the increased relative political influence of Akure as a state capital since 1976 has greatly promoted its rapid growth and increased socio economic activities (Aribigbola, 2008). Business activities are taking a new shape due to the heterogeneous massing of people into the city in search of greener pasture. This might lead to increase in the demand for food, clothing and other necessities thereby resulting into high demand for retail/shopping spaces. The need for more retail centre accommodation prompted developers who want to maximize returns on the limited available space to develop shopping complexes on multiple floors (Ezeokoli, 2012). In spite of the gesture on the part of the developers to meet demand, there seems to be vacant shop spaces in some of the shopping centres.

A number of studies have tested the relationship between vacancy rates and rent levels in the housing and commercial office market. These studies include Eubanks and Sirmans, 1979; Rosen and Smith, 1983; Rosen, 1984; Voith and Crans, 1988; Wheaton and Torto, 1994; Belsky and Goodman, 1996; Sivitanides, 1997; Gabriel and Nothaft, 2001, Hagen and Hansen, 2010. Of these studies, Wurtzebach et al. (1991) examines the effect of inflation and vacancy rates on office and industrial real estate performance. The result shows that a major difference is found between the inflation hedging effectiveness of office and industrial properties. The difference were further analysed in relation to vacancy rates in the two properties and vacancy variation was especially high for the office market but lower for the industrial market. Therefore, the relative impact of vacancy rates upon office and industrial property was found to be a significant factor in explaining returns, thus affecting inflation hedging characteristics. While this study related inflation and vacancy to real estate returns, other studies such as Rosen and Smith, 1983; Wheaton and Torto, 1988; Voith and Crane, 1988; Gabriel and Nothaft (2001) find the duration and incidence of vacancies, and natural vacancy rate, to vary significantly across metropolitan areas. Gabriel and Nothaft (2001) provide estimates of natural vacancy rates for 29 metropolitan areas that fall within a narrow range between $4 \%$ and $4.5 \%$ for a time period between 1987 - 
1996 and found out that vacancy varies significantly across metropolitan areas with a number of factors including housing costs, heterogeneity of the housing stock, tenant mobility and population growth. Wheaton and Torto (1988) allow the natural vacancy rate to vary in linear fashion with time and find a significant upward trend. Voith and Crane (1988) allow for variation over both time and space. The result showed that there is significant variation in natural vacancy rates for office space across cities, between suburban and central city markets and over time.

Although the vacancy rate in these studies varies over a time period, the basic conclusion is that the variation is significant across metropolitan areas. Furthermore, these studies used either residential or commercial office data as an indication of real estate returns. Unlike previous work, this study examines the effect of vacancy on shopping centre investment return across the city over a period of 2007 to 2012. Data on shopping centres were chosen as real estate returns since this type of study is relatively new in Nigeria which is a developing economy. Also, because of the different cultural setting in both the developed and developing country it is believed that this study will add to the body of knowledge especially in Nigeria.

\section{Methodology}

Data on rental values and vacancy rates in 35 shopping centres along five (5) major transport routes in Akure (Oba - Adesida, Oyemekun, Oke - Ijebu, Oluwatuyi, Oke Aro and Federal University of Technology,
Akure) with a total number of 1,352 rentable spaces were collected. The areas were chosen because they are the major retail areas in Akure (Table 1). Twenty (20) registered Estate Surveying firms in Akure were selected for the study. This number was taken from the 2012 register retrieved from the Secretariat of the Ondo State branch of The Nigerian Institution of Estate Surveyors and Valuers (NIESV). Questionnaire was administered on the Estate Surveying firms and seventeen (17) of them were filled and returned representing $85 \%$ response rate. The data collected were analyzed using frequency distribution tables and graph, One - Sample $\mathrm{t}$ - test and Simple Linear Regression Analysis. Graph was used to show the rental trend of the shopping centres. One sample $\mathrm{t}$ - test was used to measure the mean differences of the rental returns from the shopping centres in the study area while Simple Linear Regression Analysis was used to determine the effect of vacancy rate on the rental returns from the shopping centres. The form of regression analysis used is

$R_{i t}=a_{0}+b_{1} V A C_{t}+e_{t}$

Where:

$$
\begin{aligned}
& R_{i t}=\text { the rental return at time } t \\
& \mathrm{Vacr}_{t}=\text { Vacancy rate on shopping } \\
& \text { centres for period } t
\end{aligned}
$$

The result from the analysis of these data formed the basis for inference made in this research work.

The rate of vacancy (VAC) was obtained using the formula;

Vacancy Rate $=\frac{\text { vacant spaces }\left(\mathrm{m}^{2}\right)}{\text { total spaces }\left(\mathrm{m}^{2}\right)} \times 100$ 
Table 1: Operationalization of Variables

\begin{tabular}{lll}
\hline Variable & Definition of Variables & Measurement \\
\hline RV & Rental Value & Actual (N) \\
VACR & Vacancy Rate & Actual (\%) \\
\hline
\end{tabular}

Table 2: Total Number of Shopping Spaces in the study areas

\begin{tabular}{lccc}
\hline Selected areas & Number of Shopping centres & $\begin{array}{c}\text { Number of Spaces in } \\
\text { shopping centre }\end{array}$ & Vacant Spaces \\
\hline Oba Adesida & 06 & 283 & 02 \\
Oyemekun & 07 & 185 & 07 \\
Oke - Ijebu & 07 & 257 & 95 \\
Oluwatuyi & 08 & 260 & 19 \\
Oke - Aro & 04 & 263 & 46 \\
FUTA & 03 & 104 & 0 \\
TOTAL & 35 & $1352^{*}$ & $169^{*}$ \\
\hline
\end{tabular}

\section{Results and Discussion}

Table 3: Average Vacancy Rate in Shopping Centres According to Location

\begin{tabular}{llll}
\hline Centre Location & Total Space $\left(\mathrm{M}^{2}\right)$ & Vacant Space $\left(\mathrm{M}^{2}\right)$ & Vacancy Rate $(\%)$ \\
\hline Oba Adesida & 2807.93 & 13.94 & 0.50 \\
Oyemekun & 2353.55 & 105.85 & 4.50 \\
Oke Ijebu & 3609.39 & 1274.13 & 35.30 \\
Oluwatuyi & 3061.43 & 222.60 & 7.27 \\
Oke Aro & 3397.68 & 627.27 & 18.46 \\
FUTA & 1182.71 & 0.00 & 0.00 \\
Total & 16412.69 & 2243.79 & 13.67 \\
\hline
\end{tabular}

In Table 3 above, Shopping Centres along FUTA and Oba Adesida roads recorded the lowest average vacancy rates of $0.00 \%$ and $0.50 \%$ respectively, while shopping centres along Oyemekun has vacancy rate of $4.50 \%$. On the other hand, Oke Ijebu has the highest average vacancy rate of $35.30 \%$, followed by Oke - Aro with average vacancy rate of $18.46 \%$. Centres along Oluwatuyi have vacancy rate of $7.27 \%$ which is still low compared to other areas. The result can be attributed to the fact that Oba Adesida and Oyemekun road are the core areas of Akure where commercial activities are at their peaks, thus causing demand for shopping spaces to be high in these areas. On the other hand, the Federal University of Technology, Akure (FUTA) as an institution creates its own niche due to the demand of the students as noted by Peacocke (1999) that one of the major characteristics of students demand is that it monopolizes the market. Thus, centres close to it are bound to boom with economic activities due to the presence of students. Hence, shopping centres along the Federal University of Technology, Akure (FUTA), Oba Adesida and Oyemekun roads are performing better than that of Oke - Ijebu and Oke - Aro with high vacancy rate of $35.30 \%$ and $18.46 \%$ respectively. Shopping centres along OkeIjebu and Oke-Aro can be said to be at distress point as suggested by Costar Group 
(2010) that any shopping centre with vacancy rate above $15 \%$ is in distress. Therefore, this level of vacancy could have significant effect on the total realisable rental income from shopping centres and hence, on the retail property market in Akure.

Table 4: Rental Value per Square Metre of Shopping Spaces from 2007 - 2012

\begin{tabular}{|c|c|c|c|c|c|c|c|}
\hline Location & 2007 & 2008 & 2009 & 2010 & 2011 & 2012 & Growth Rate (\%) \\
\hline \multicolumn{8}{|l|}{ ADESIDA } \\
\hline Moses & - & 6000 & 6000 & 6000 & 6000 & 6000 & .00 \\
\hline Oluwatobi & 3200 & 3700 & 3700 & 5200 & 5200 & 5200 & 9.00 \\
\hline Dan Adu & - & 5500 & 5500 & 5500 & 6500 & 6500 & 6.00 \\
\hline Olukayode & 3100 & 3400 & 4200 & 4600 & 5400 & 6900 & 12.00 \\
\hline Arowolo & 3400 & 3800 & 4600 & 5000 & 5700 & 5700 & 9.00 \\
\hline GAB & - & 5700 & 5700 & 5700 & 5700 & 5700 & .00 \\
\hline \multicolumn{8}{|l|}{ OYEMEKUN } \\
\hline YemSam & - & - & - & 3700 & 3700 & 3700 & .00 \\
\hline Ogunlalaka & 3100 & 3100 & 3100 & 3100 & 3100 & 3100 & .00 \\
\hline Archade & 2300 & 3100 & 3100 & 3100 & 3800 & 3800 & 8.00 \\
\hline POWA HQ & - & - & - & & 5500 & 5500 & .00 \\
\hline Olorunlagba & - & - & - & 3200 & 3200 & 3200 & .00 \\
\hline Omokinde & 2900 & 2900 & 2300 & 2300 & 2300 & 2300 & -4.00 \\
\hline SayYou & 3100 & 4000 & 4000 & 4000 & 5000 & 5000 & 7.00 \\
\hline \multicolumn{8}{|l|}{ OKE IJEBU } \\
\hline Clement & 4200 & 4200 & 4200 & 4200 & 4200 & 4200 & .00 \\
\hline Rufus & 2000 & 2000 & 2000 & 2000 & 2000 & 2000 & .00 \\
\hline Tobbi & - & - & 2300 & 2300 & 2300 & 2300 & .00 \\
\hline Olufunmilayo & - & - & - & 2000 & 2000 & 2000 & .00 \\
\hline Josabol & - & - & - & 1800 & 1500 & 1500 & -7.00 \\
\hline New Park & - & - & - & 1600 & 1600 & 1600 & .00 \\
\hline Ajoyemi & - & - & - & 1300 & 1300 & 1300 & .00 \\
\hline \multicolumn{8}{|c|}{ OLUWATUYI } \\
\hline Emilia & - & - & 3400 & 3400 & 3400 & 4300 & 6.00 \\
\hline Raimed & - & 2800 & 3400 & 3400 & 4600 & 4600 & 11.00 \\
\hline Kikiowo & - & - & - & 2300 & 1800 & 1800 & -7.00 \\
\hline JAAK & 900 & 900 & 1050 & 1050 & 1050 & 1400 & 8.00 \\
\hline Daniels & - & - & 1800 & 1800 & 1800 & 1800 & .00 \\
\hline Anifowose & - & 1800 & 1800 & 1800 & 2300 & 2300 & 5.00 \\
\hline \multicolumn{8}{|l|}{ OKE ARO } \\
\hline Yomisola & 900 & 900 & 1400 & 1400 & 1400 & 1400 & 7.00 \\
\hline IJK Centre & - & - & - & - & 1900 & 1900 & .00 \\
\hline Hephziba & 1100 & 1100 & 1400 & 1400 & 1800 & 1800 & 6.00 \\
\hline Stefal & 2200 & 2200 & 2200 & 2200 & 2200 & 2200 & .00 \\
\hline Omojowo & - & - & - & 2300 & 2300 & 2300 & .00 \\
\hline BDivisio & - & - & - & 2300 & 2300 & 2300 & .00 \\
\hline \multicolumn{8}{|l|}{ FUTA } \\
\hline Ajuola & - & - & - & - & 6700 & 6700 & .00 \\
\hline Adejuyig & 2300 & 2300 & 2300 & 2300 & 2300 & 2750 & 3.00 \\
\hline Atolagbe & 1900 & 1900 & 1900 & 2300 & 2300 & 2300 & 7.00 \\
\hline
\end{tabular}




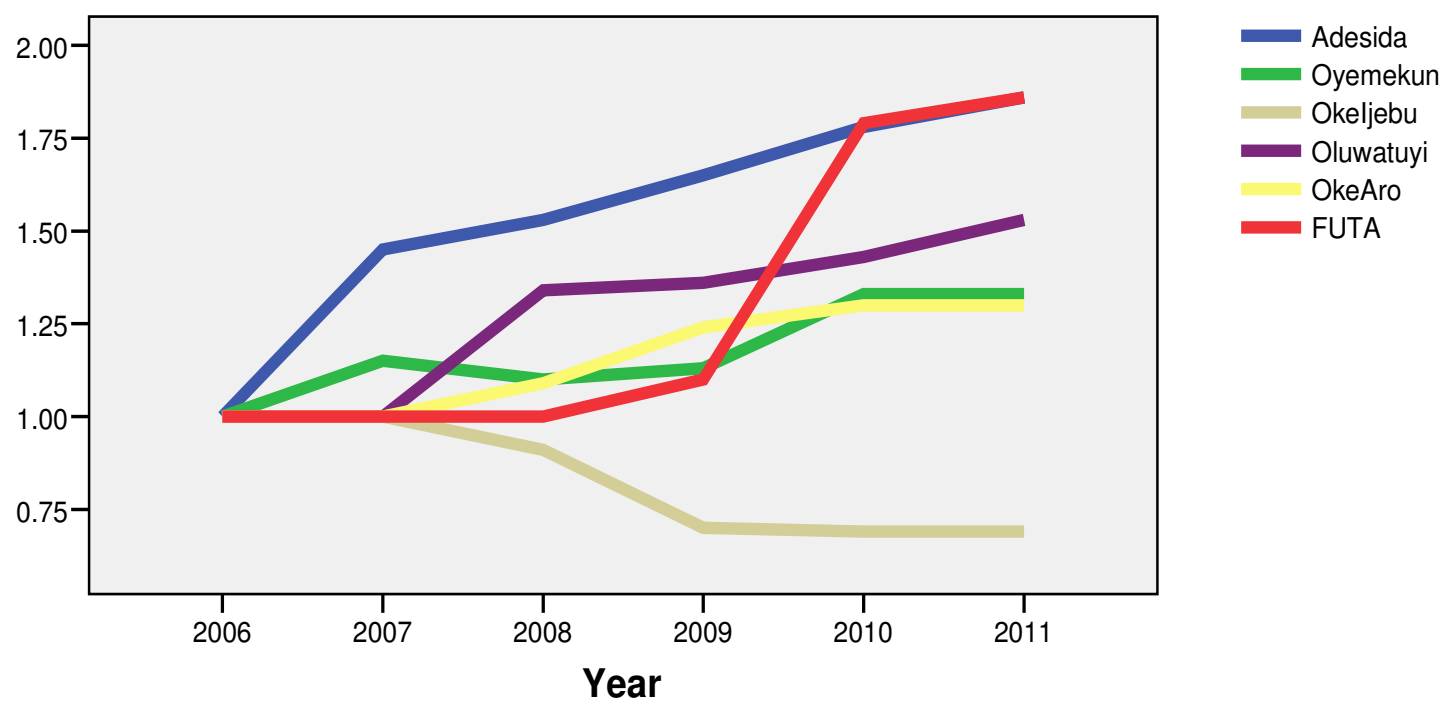

Figure 1: Rental Trend of Shopping Centres by Location

The rent per meter square in Table 4 was indexed to have the same base year for easy analysis. In Table 4 and figure 1 , the Rent per meter square $\left(\right.$ Rent $\left./ \mathrm{m}^{2}\right)$ of shopping spaces in the various shopping canters was shown to vary across locations. Shopping Centres along Oke Ijebu and Oke Aro showed poor rental growth in the years under study (2007 to 2012). For instance, while spaces in other shopping centres were showing increase in value over the years (an upward trend), Oke - Ijebu did not witness growth in any of the centres. Instead Josabol witnessed a fall in rental value from $\mathrm{N} 1,800 / \mathrm{m}^{2}$ of space in 2010 to $\mathrm{N} 1,500 / \mathrm{m}^{2}$ in 2011 and 2012 respectively. This could be in order to retain tenants in the shopping centre as suggested by Frank
(2010). In addition, Oke - Aro only experienced growth in Yomisola shopping centre from $\mathrm{N} 900 / \mathrm{m}^{2}$ in 2008 to $\mathrm{N} 1,400 / \mathrm{m}^{2}$ in 2009 and the growth remained constant through 2009 to 2012. Also, in Hephziba shopping centre in Oke - Aro, witnessed growth in rentals in $2010\left(\mathrm{~N} 1,400 / \mathrm{m}^{2}\right)$ and the amount rose to $\mathrm{N} 1800 / \mathrm{m}^{2}$ in 2012 . This may be attributed to high vacancy rates experienced in centres in the two locations as depicted in the table. The high vacancy rate might have been as a result of supply being more than demand in these locations. Benjamin et al. (1998) argued that oversupply of shopping spaces can cause vacancy in some centres due to shift in demand to other centres. 
Table 5: One-Sample Statistics of Shopping Centres' Rental Values between 2007 and 2012

\begin{tabular}{|c|c|c|c|c|c|c|}
\hline Shopping Centres & $\mathrm{N}$ & Mean & Std. Dev & $\begin{array}{l}\text { T-Statistics Test } \\
\text { Value }=1\end{array}$ & Df & Sig. (2-tailed) \\
\hline Moses & 5 & 1.0000 & .00000 (a) & - & - & - \\
\hline Oluwatobi & 6 & 1.3800 & .29230 & 3.184 & 5 & $.024 *$ \\
\hline Dan Adu & 5 & 1.0720 & .09859 & 1.633 & 4 & .178 \\
\hline Olukayode & 6 & 1.4600 & .37529 & 3.002 & 5 & $.030 *$ \\
\hline Arowolo & 6 & 1.3700 & .27964 & 3.241 & 5 & $.023^{*}$ \\
\hline GAB & 5 & 1.0000 & $.00000(a)$ & - & - & - \\
\hline YemSam & 3 & 1.0000 & .00000 (a) & - & - & - \\
\hline Ogunlalaka & 6 & 1.0000 & $.00000(a)$ & - & - & - \\
\hline Archade & 6 & 1.3650 & .22242 & 4.020 & 5 & $.010^{*}$ \\
\hline POWAHQ & 2 & 1.0000 & .00000 (a) & - & - & - \\
\hline Olorunlagba & 3 & 1.0000 & $.00000(a)$ & - & - & - \\
\hline Omokinde & 6 & .8667 & .10328 & -3.162 & 5 & $.025^{*}$ \\
\hline SayYou & 6 & 1.3167 & .18348 & 4.227 & 5 & $.008^{*}$ \\
\hline Clement & 6 & 1.0000 & $.00000(a)$ & - & - & - \\
\hline Rufus & 6 & 1.0000 & $.00000(a)$ & - & - & - \\
\hline Tobbi & 4 & 1.0000 & $.00000(a)$ & - & - & - \\
\hline Olufunmilayo & 3 & 1.0000 & $.00000(a)$ & - & - & - \\
\hline Josabol & 3 & .8667 & .11547 & -2.000 & 2 & .184 \\
\hline New Park & 3 & 1.0000 & $.00000(a)$ & - & - & - \\
\hline Ajoyemi & 3 & 1.0000 & $.00000(a)$ & - & - & - \\
\hline Emilia & 4 & 1.0625 & .12500 & 1.000 & 3 & .391 \\
\hline Raimed & 5 & 1.3680 & .29397 & 2.799 & 4 & $.049 *$ \\
\hline Kikiowo & 3 & .8667 & .11547 & -2.000 & 2 & .184 \\
\hline Jaak & 6 & 1.2000 & .21909 & 2.236 & 5 & .076 \\
\hline Daniels & 4 & 1.0000 & .00000 (a) & - & - & - \\
\hline Anifowose & 5 & 1.1000 & .13693 & 1.633 & 4 & .178 \\
\hline Yomisola & 6 & 1.3333 & .25820 & 3.162 & 5 & $.025^{*}$ \\
\hline IJK Centre & 2 & 1.0000 & $.00000(a)$ & - & - & - \\
\hline Hephzibah & 6 & 1.2400 & .19616 & 2.997 & 5 & $.030^{*}$ \\
\hline Stefal & 6 & 1.0000 & $.00000(a)$ & - & - & - \\
\hline Omojowo & 3 & 1.0000 & .00000 (a) & - & - & - \\
\hline B-Division & 3 & 1.0000 & .00000 (a) & - & - & - \\
\hline Ajuola & 2 & 1.0000 & .00000 (a) & - & - & - \\
\hline Adejuyigbe & 6 & 1.0333 & .08165 & 1.000 & 5 & .363 \\
\hline Atolagbe & 6 & 1.2400 & .26291 & 2.236 & 5 & .076 \\
\hline
\end{tabular}

$(*$ Significant at 0.05$)$

From table 5, the mean rental returns from Oluwatobi, Olukayode, Arowolo, SayYou Plaza, Raimed Yomisola and Hephzibah are significantly higher than the observed T-statistics, indicating that these shopping centres are significantly producing annual rental returns above the t-value. However, the mean rental return from Omokinde shopping centre is significantly lower than the observed t- statistics value, indicating a reduction in annual rental values of the centre over the period of study. The mean scores of 1.0 exhibited by some shopping centres in the Table revealed that there is no growth in the rental returns from the centres over the period of study. This might be as a result of the vacancy in some of the shopping spaces. To curb this, rents were fixed to retain tenants. The centres with significantly higher t-value are performing 
better than others and have the prospect of rental growth provided the centres are always fully occupied or highly demanded for (effective demand). This is why landlords of such centres often increase rents knowing that the tenants will pay, whereas the Landlords of the centres with tvalue less than and/or equal to 1.00 are still struggling to retain tenants in them by reducing or maintaining fixed rent passing on these centres.

The result of the analysis in Table 6 below shows that there is considerably high percentage difference between the actual rentals received and the expected rentals from the shopping centres with high vacancy rate. For instance, due to the high vacancy rate experienced in Clement and New park shopping centres, the percentage difference between their expected and actual rental return are $81.82 \%$ and $110.39 \%$ respectively. From the table it can be seen that vacancy rate has a direct correlation with deviation of actual return from the expected returns. The implication of this is that high level of vacancy could depict unprofitability of an investment and this can lead to poor performance of such investment. Therefore, every prudent investor ought to work at avoiding excessive vacancy rate in their property so as to maintain high performance.

Table 6: Percentage difference between Actual and Expected Rental Returns from the Shopping Centres

\begin{tabular}{lllllll}
\hline $\begin{array}{l}\text { Shopping } \\
\text { Centre }\end{array}$ & $\begin{array}{l}\text { Total Space } \\
\left(\mathrm{M}^{2}\right)\end{array}$ & $\begin{array}{l}\text { Vacant } \\
\text { Space }\left(\mathrm{M}^{2}\right)\end{array}$ & $\begin{array}{l}\text { Vacancy } \\
\text { Rate }(\%)\end{array}$ & $\begin{array}{l}\text { Expected Rental } \\
\text { Income (N) }\end{array}$ & $\begin{array}{l}\text { Actual } \\
\text { Rentals } \\
\text { Income (N) }\end{array}$ & $\%$ Diff. \\
\hline Oba Adesida & & & & & & \\
Moses & 146.30 & 0.00 & 0.0 & 877800.00 & 877800.00 & 0.00 \\
Oluwatobi & 731.81 & 13.94 & 1.9 & 3805400.00 & 3732910.00 & 1.94 \\
Dan Adu & 283.14 & 0.00 & 0.0 & 1840410.00 & 1840410.00 & 0.00 \\
Olukayode & 940.90 & 0.00 & 0.0 & 6492210.00 & 6492210.00 & 0.00 \\
Arowolo & 588.06 & 0.00 & 0.0 & 2587460.00 & 2587460.00 & 0.00 \\
GAB & 117.72 & 0.00 & 0.0 & 675740.00 & 675740.00 & 0.00 \\
Oyemekun & & & & & & 25.00 \\
YemSam & 163.35 & 32.67 & 20.0 & 604400.00 & 483520.00 & 0.00 \\
Ogunlalaka & 182.95 & 0.00 & 0.0 & 567150.00 & 567150.00 & 0.00 \\
Omonije Archade & 601.13 & 0.00 & 0.0 & 2284290.00 & 2284290.00 & 0.00 \\
POWA H/Q & 196.02 & 0.00 & 0.0 & 1078110.00 & 1078110.00 & 0.00 \\
Olorunlagba & 230.00 & 20.91 & 9.1 & 726800.00 & 660730.00 & 10.00 \\
Omokinde & 522.72 & 52.27 & 10.0 & 1202256.00 & 1082030.00 & 11.11 \\
SayYou & 457.38 & 0.00 & 0.0 & 2286900.00 & 2286900.00 & 0.00 \\
Oke - Ijebu & & & & & & \\
Clement & 261.36 & 117.61 & 45.0 & 1097712.00 & 603742.00 & 81.82 \\
Rufus & 196.02 & 0.00 & 0.0 & 392040.00 & 392040.00 & 0.00 \\
Tobbi & 250.91 & 0.00 & 0.0 & 577083.00 & 577083.00 & 0.00 \\
Olufunmilayo & 365.90 & 45.74 & 12.5 & 731810.00 & 640330.00 & 14.29 \\
Josabol & 261.36 & 0.00 & 0.0 & 384200.00 & 384200.00 & 0.00 \\
New Park & 2117.02 & 1110.78 & 52.5 & 3387230.00 & 1609980.00 & 110.39 \\
Ajoyemi & 156.82 & 0.00 & 0.0 & 200000.00 & 200000.00 & 0.00 \\
Oluwatuyi & & & & & & \\
\hline
\end{tabular}




\begin{tabular}{lllllll}
\hline Emilia & 264.88 & 6.97 & 2.5 & 900456.00 & 876758.00 & 2.70 \\
Raimed & 209.09 & 0.00 & 0.0 & 574992.00 & 574992.00 & 0.00 \\
Kikiowo & 457.38 & 26.14 & 5.7 & 1051974.00 & 991861.00 & 6.06 \\
Jaak & 1006.24 & 0.00 & 0.0 & 1408730.00 & 1408730.00 & 0.00 \\
Daniels & 444.31 & 39.20 & 8.8 & 799762.00 & 729194.00 & 9.68 \\
Anifowos & 169.88 & 26.14 & 15.4 & 390000.00 & 330000.00 & 18.18 \\
Yomisola & 313.63 & 91.48 & 29.2 & 439085.00 & 311018.00 & 41.18 \\
IJK Centre & 196.02 & 32.67 & 16.6 & 372438.00 & 310365.00 & 20.00 \\
Oke - Aro & & & & & & \\
Hephziba & 2012.47 & 548.86 & 27.3 & 3622450.00 & 2634509.00 & 37.50 \\
Stefal & 196.02 & 0.00 & 0.0 & 431244.00 & 431244.00 & 0.00 \\
Omojowo & 849.42 & 78.41 & 9.2 & 1953666.00 & 1773327.00 & 10.17 \\
POWA B/D & 339.77 & 0.00 & 0.0 & 781466.00 & 781466.00 & 0.00 \\
FUTA & & & & & & \\
Ajuola & 271.81 & 0.00 & 0.0 & 1821156.00 & 1821156.00 & 0.00 \\
Adejuyigbe & 362.04 & 0.00 & 0.0 & 995610.00 & 995610.00 & 0.00 \\
Atolagbe & 548.86 & 0.00 & 0.0 & 1262369.00 & 1262369.00 & 0.00 \\
\hline
\end{tabular}

Table 7: Summary of Model of the Effect of Vacancy Rate on Rental Values of the Shopping Centres

\begin{tabular}{lllll}
\hline Model & $\mathrm{R}$ & $\mathrm{R}$ Square & $\begin{array}{l}\text { Adjusted R } \\
\text { Square }\end{array}$ & $\begin{array}{l}\text { Std. Error of the } \\
\text { Estimate }\end{array}$ \\
\hline 1 & $.308(\mathrm{a})$ & .095 & .068 & 1702.67714 \\
\hline
\end{tabular}

Table 8: Analysis of Variance

\begin{tabular}{llllll}
\hline Model & Sum of Squares & Df & Mean Square & F & Sig. \\
\hline Regression & 10054102.873 & 1 & 10054102.873 & 3.468 & .071 \\
Residual & 95670611.412 & 33 & 2899109.437 & & \\
Total & 105724714.286 & 34 & & & \\
\hline
\end{tabular}

Table 9: Regression Coefficient of the Effect of Vacancy Rate on Shopping Centres Rental Values

\begin{tabular}{lllcll}
\hline Model & \multicolumn{2}{c}{$\begin{array}{c}\text { Unstandardized } \\
\text { Coefficients }\end{array}$} & $\begin{array}{c}\text { Standardized } \\
\text { Coefficients }\end{array}$ & T & Sig. \\
\cline { 2 - 4 } & $\mathrm{B}$ & \multicolumn{2}{c}{ Std. Error } & Beta & \\
\hline (Constant) & 3668.427 & 333.986 & & 10.984 & .000 \\
Vacancy Rate & -41.569 & 22.322 & -.308 & -1.862 & $.071^{*}$ \\
\hline
\end{tabular}

$\mathrm{R}=0.308, \mathrm{R}^{2}=0.095$, Adjusted $\mathrm{R}^{2}=0.068$.

(* significant at 0.10 )

Table 7 reveals the coefficient of determination $\left(\mathrm{R}^{2}\right)$ as 0.095 indicating that $9.5 \%$ of the sample variation in shopping centres rental value is attributed to changes in vacancy rate, while the other $90.5 \%$ variation could be attributed to other factors not considered in this paper. However, table 9 further revealed that the relationship between vacancy rate and rental values of shopping centre is inverse and weak (- 
0.308) though not significant at 0.05 significant levels (0.071). But at 90\% confidence level, it can be said that vacancy rate has a causal effect on rental values of shopping centres in Akure.

Thus, the model can be re-written as:

\section{$\mathrm{RV}=3668.427-41.569 \mathrm{VACR}+\mathrm{e}$}

This shows that a unit change in vacancy rate causes -41.569 units of change in the rental value of shopping centres. The implication of this is that as vacancy rate is increasing the rent per meter square in the shopping centres decreases. This is because tenants would seek centres where volume of sales is high; therefore owners of vacant centres will have to reduce rents to retain tenants. The result is consistent with the findings of Hartzell and Webb (1993), which discovered that the return-vacancy relationship is generally negative and significant i.e. vacancy rate in commercial property negatively affects the expected returns from the property. Also, the study of Frank (2010) on the global real estate management in Europe revealed that with low demand for space in a property and vacancy rates rising, landlords have had to offer reduced rents and significantly increased incentives in order to attract or retain tenants. This reduced rents coupled with some level of vacancies in shopping centres have caused high variance between expected and the actual rental income as shown in table 6. Some landlords are sometimes forced to convert shopping centres to other uses like residential due to poor performance.

\section{Conclusion}

The paper focused on the effect of vacancy rate on shopping centres investment returns in selected areas of Akure. From the analysis, it was found that the average rate of vacancy in shopping centres in Akure is $13.67 \%$. The result also, shows that centres in Oba Adesida, Oyemekun and FUTA experienced low vacancy rate. Oba Adesida and Oyemekun are in the core of the city where commercial activity is most pronounced while FUTA as an institution creates its own niche. However, vacancy rate in Oke Ijebu and Oke - Aro are high, thereby affecting the expected returns from the centres. Furthermore, it was shown that Vacancy rate has a negative effect on the rental values of shopping centres in Akure indicating that an increase in vacancy rate will cause a decrease in the expected rental value. It is therefore, recommended that the shopping centre developers should employ the services of the Estate Surveyors and Valuers to carry out feasibility and viability appraisal of the project. This gesture will check over supply of centres. Estate Surveyors and Valuers should work in conjunction with the shopping centres owners in fixing the rent of the centres as this will forestall excess rent charged by owners which invariably may cause vacancy.

\section{References}

Aribigbola, A. (2008). Housing Policy Formulation in Developing Countries; Evidence from programme Implementation from Akure, Ondo State, Nigeria. Journal of Humanity Ecology, 23(2): 125 - 134.

Bello, V.A. (2012). The Determinants of Shopping Center rents in Akure, Nigeria. TS04G - Valuation - Mass Appraisal Techniques 6054, Knowing to manage the territory, protect the environment, evaluate the cultural heritage. Proceedings of the annual FIG Working Week, 6 - 10 May.

Belsky, E. and Goodman, J.L. (1996). Explaining the Vacancy rate - Rent 
Paradox of the 1980s. Journal of Real Estate Research, 11(3): 309 - 323.

Benjamin J.D., Jud, G.D, and Winkler, D.T. (1995). An analysis of shopping centre Investment. Journal of Real Estate Finance and Economics, 10 (2): 161 68.

Benjamin J.D., Jud, G.D, and Winkler, D.T. (1998), Retail Space Demand and Supply: An Integrative Model Retrieved from: http://www.reri.org (October 5, 2010)

Costar Group (2010) Regional Real Estate Report. Retrieved from: http://www.costar.com (November 4, 2010)

Eubank, A.A. and Sirmans, C.F. (1979). The Price Adjustment Mechanism for Rental Housing in the United States. Quarterly Journal of Economics, 93: $163-183$.

Ezeokoli, N.B. (2012). Analysis of Vacancy Rate in Shopping Centres in Akure. An Unpublished M.Tech Thesis Submitted to The Department of Estate Management, Federal University of Technology, Akure.

Ezeokoli, N.B., Bello, V.A and Adebisi, O.S. (2012). Determinants of Vacancy Rate in Shopping Centres in Akure, Nigeria. In Laryea et al. (Eds). Proceedings of the $4^{\text {th }}$ West Africa Built Environment Research (WABER) Conference, Abuja, July $24^{\text {th }}-26^{\text {th }}$.

Frank, K. (2010). Global Real Estate Markets. Annual Review and Outlook. www.knightfrank.com

Gabriel, S.A. and Nothaft, F.E. (2001). Rental Housing Market, the Incidence and Duration of Vacancy and the Natural Vacancy Rate. Journal of Urban Economics, 49: 121 - 149.

Gerbich, M. (1998). Shopping Center Rentals: An Empirical Analysis of the
Retail Tenant Mix. Journal of Real Estate Research, 15(3): 1-10.

Hagen, D.A. and Hansen, J.L. (2010). Rental Housing and the Natural Vacancy Rate. Journal of Real Estate Research, 32(4): $413-433$

Hartzell, D.J. and Webb, R.B. (1993). Commercial Real Estate and Inflation during Periods of High and Low Vacancy Rates. Retrieved from: http://www.reri.org (October 4, 2010)

Peacocke, H. (1999). 'Fallow field', Roof, September/October

Pristin, T. (2008). A Squeeze on Retailers Leaves Holes in Malls, The New York Times. Retrieved from: http://www.nytco.com. (October 22, 2010)

Rosen, K.T. (1984). Towards a Model for the Office Building Sector, Journal of American Real Estate and Urban Economics Association, 84(12): 261 269

Rosen, K.T. and Smith, L. (1983). The Price Adjustment Process for Rental Housing and the Natural Vacancy Rate, American Economic Review, 73: 779 786.

Sivitanides, P.S. (1997). The Rent Adjustment Process and the Structural Vacancy Rate in the Commercial Real Estate Market. Journal of Real Estate Research. 13(2): 195 - 209.

Smith, L.B. (1974). A Note on the Price Adjustment Mechanism for Rental Housing, American Economic Review, 63(3): $478-481$.

Wheaton, W. and Torto, R. (1994). Office rent Indices and their Behaviour over Time. Journal of Urban Economics, 35: $121-139$.

Voith, R. and Crone, T. (1988). National Vacancy Rates and the Persistence of Shocks in U.S. Office Markets. AREUEA Journal, 16(4): 437 - 458. 